\title{
Histone H4
}

National Cancer Institute

\section{Source}

National Cancer Institute. Histone H4. NCI Thesaurus. Code C16686.

Histone $\mathrm{H} 4$ (103 aa, $11 \mathrm{kDa}$ ) is encoded by the human $\mathrm{H} 4 \mathrm{C} 1, \mathrm{H} 4 \mathrm{C} 2, \mathrm{H} 4 \mathrm{C} 3, \mathrm{H} 4 \mathrm{C} 4$, $\mathrm{H} 4 \mathrm{C} 5, \mathrm{H} 4 \mathrm{C} 6, \mathrm{H} 4 \mathrm{C} 6, \mathrm{H} 4 \mathrm{C} 8, \mathrm{H} 4 \mathrm{C} 9, \mathrm{H} 4 \mathrm{C} 11$, H4C12, H4C13, H4C14, H4C15, H4-16 genes.

This protein plays a role in nucleating the formation of high order chromatin structures as a part of nucleosomes. 